“強い”正動都集団の機能的特性について

一高校サツカー部の毫例研究一

大㕹体有大学非四国敬

目的：“強い”スポーツ集団では凝集性が高いと言” われている，そこで，トップ・レベルの一尚校サッカー 部の凝集性をソシオメトリツク・テストにより検討し， 同時に，面接調査により，その高まる条件を考察する。

方法：対象は大阪府下のM高サッカー部の部員 26 名 と部員導考について調监した，部員に対するンシォメト リック・テストは「部の内外を閣わず最も親しい人を 3 名」と「部队最も親しい人を3名」を選択させた。そ

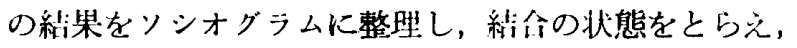
Katz と Powell の式により凝集性指数を算出した。

結果:

(A) 凝集性について

1）部内の絬会状態は (1) 全体は学年単位の3つの集 団から構成されている，(2) 学年間の結合はあまり見ら れない. (3) 各学年の絬合は，3年は主将を中心にして 強固に絬合し，2 年:では補火，正選手の一部の坬立があ り，絬合はあまり茺くない１众は特別の小心はない
が，網状の強固な結合である。

2）部の内外を問わず最も親しい人を3名選択させた 埸合，部外者を選択したのは３金が平均0.7名，2年が 2.3 名，1 俳が1.0名である。これより，3年，1年では 視しい友人が名んど部队に限られているのに対し，2年 は部外の者と多くの交友関係を持つている.

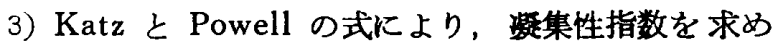
ると, (1) 3 年が $0.444,2$ 年が $0.264,1$ 年が 0.467 で ある. (2) 部全体の指数は0.534である。以上,この部 の絬命の状態を概観したが，全国似にトップ・レベルに ある強いM高サツカ一部の凝集性は相当简いといえる。

(B)この部の凝集性を间めている条件についての考 察は省略する。

まとめ：この部の㠜集性を高めている主な条件とし て，部員のモラール，部の雾囲気，O.B. を含めた指導 者の熱意，周囲の支援等があげられる.そにらの条件に より, 部の凝集性は高められ，その結果として，伝統的 に輝しい戦積を残していると考えられる。

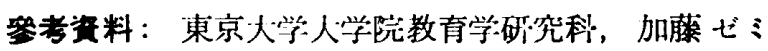
ナール「问格連動部の矿究」籍1 献〜第 4 報.

\section{スボーツによる性格治泰の研究（その IV）}

\begin{tabular}{|c|c|c|}
\hline 順犬堂大学 & & O太 山哲 罗 \\
\hline 東京教有人”学 & 鈴朴 & 清，松山 岩歹 \\
\hline & 近藤 & 充夫，山r \\
\hline & 松永 & 春代 \\
\hline
\end{tabular}

少众非行の問題は，これに闵する諸科兴心の発達と，そ れらをとり入れた新しい法律や制度の整備や，関係者の 努力にもかかわらず，ますます㳭刻になつてきいる。

この問題を解明するために, 従来, 関係諸利学がそれ ぞれの領域で研究をすすめてきているが，体有を組蟣的

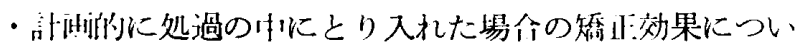
ての湖究は，まだ十分に検剖されていない段階である。

そこで，われわれは，とくに，職業補導を縮少し，主 として体有による镉正効果を目的としている某少年院の 院生を刘象として，スポーツによる性格治療を実験的仡 究明しょらとするるのである。

この某少年院は, 現在, 体育に上る処遇実験の段階に あり，しかも重大な問題行動を犯した院生を対象にして いるので，稪正手段としての休育指導の内容や方法の尖 効をあげるなめには，種ヶな問題を内包している.
そこで，現状を知る力法として，まず，稪正教育の手 段として笑施している体育についての院生の受けとめ方 を把握するために，孙備的な態度調查を行ならととも に，各教官による体育の授業時に批ける院生の行動観察 を試みた。

予備的態度調查の項目は，体有の身体的・精神的・社 会的な効果についての次元および体育実拔のカリキュラ ムの次元に関するるのである. 意見項目に対する反心の させ方は，「賛成」，「どちらでもない」，「反対」の 了件法を用いた。

各意見をランダムに配列して作成した調查表を 72 名 の院生に，胎利40 作10月15日と12 月9日の 2 回にわ たつで施した。

その秥果，1回目と 2 回日を比較すると，全般的には 问㥞な傾向を亦し，とくに体有の精神的効果を認める意 見が多かつたが，体育の場において友人ができにくくな り，運動技能の学習への要求の增大が見られた。

行動観察については，院生の意見と必ずしも刘心した 関係がみられず，問題の複雑さを暗示している。 